\title{
Follow-Up Intervals for Breast Imaging Reporting and Data System Category 3 Lesions on Screening Ultrasound in Screening and Tertiary Referral Centers
}

\author{
Sun Huh, $M D^{1}$, Hee Jung Suh, $M D^{2}$, Eun-Kyung Kim, $M D, P h D^{1}$, Min Jung Kim, $M D, P h D^{1}$, \\ Jung Hyun Yoon, MD, PhD ${ }^{1}$, Vivian Youngjean Park, MD, PhD ${ }^{1}$, Hee Jung Moon, MD, PhD ${ }^{1}$ \\ ${ }^{1}$ Department of Radiology, Research Institute of Radiological Science, Severance Hospital, Yonsei University College of Medicine, Seoul, Korea; \\ 2Department of Radiology, Severance Check-Up, Seoul, Korea
}

Objective: To assess the appropriate follow-up interval, and rate and timepoint of cancer detection in women with Breast Imaging Reporting and Data System (BI-RADS) 3 lesions on screening ultrasonography (US) according to the type of institution. Materials and Methods: A total of 1451 asymptomatic women who had negative or benign findings on screening mammogram, BI-RADS 3 assessment on screening US, and at least 6 months of follow-up were included. The median follow-up interval was 30.8 months (range, 6.8-52.9 months). The cancer detection rate, cancer detection timepoint, risk factors, and clinicopathological characteristics were compared between the screening and tertiary centers. Nominal variables were compared using the chisquare or Fisher's exact test and continuous variables were compared using the independent $t$ test or Mann-Whitney $\mathrm{U}$ test. Results: In 1451 women, 19 cancers (1.3\%) were detected; two $(0.1 \%)$ were diagnosed at 6 months and $17(1.2 \%)$ were diagnosed after 12.3 months. The malignancy rates were both $1.3 \%$ in the screening ( 9 of 699$)$ and tertiary (10 of 752$)$ centers. In the screening center, all nine cancers were invasive cancers and diagnosed after 12.3 months. In the tertiary center, two were ductal carcinomas in situ and eight were invasive cancers. Two of the invasive cancers were diagnosed at 6 months and the remaining eight cancers newly developed after 13.1 months.

Conclusion: One-year follow-up rather than 6-month follow-up may be suitable for BI-RADS 3 lesions on screening US found in screening centers. However, more caution is needed regarding similar findings in tertiary centers where 6 -month follow-up may be more appropriate.

Keywords: Screening; Breast cancer; Ultrasound; Mammography

\section{INTRODUCTION}

Breast cancer screening focuses on detecting occult cancer in its early stages without lymph node metastasis

Received: October 8, 2019 Revised: March 10, 2020

Accepted: March 12, 2020

This study was supported by a faculty research grant of Yonsei University College of Medicine (6-2017-0045).

Corresponding author: Hee Jung Moon, MD, PhD, Department of Radiology, Research Institute of Radiological Science, Severance Hospital, Yonsei University College of Medicine, 50-1 Yonsei-ro, Seodaemun-gu, Seoul 03722, Korea.

- E-mail: artemis4u@yuhs.ac

This is an 0pen Access article distributed under the terms of the Creative Commons Attribution Non-Commercial License (https://creativecommons.org/licenses/by-nc/4.0) which permits unrestricted non-commercial use, distribution, and reproduction in any medium, provided the original work is properly cited. and distant spread (1). Although mammography is the only screening method proven to reduce mortality so far, its sensitivity varies, ranging $80-98 \%$ in women with fatty breast tissue to $30-48 \%$ in women with dense breast tissue $(2,3)$. Breast ultrasonography (US) is an attractive supplemental screening tool in women with dense breast tissue and the addition of US to screening mammography increases cancer detection yield by 1.9 to 6.8 cancers per 1000 women (2, 4-12). However, adding screening US results in increased cost, increased false-positive US examination findings, and higher benign biopsy rates (1316). One reason for false-positive US results is the category 3 assessment of the American College of Radiology (ACR) Breast Imaging Reporting and Data System (BI-RADS) (17). The BI-RADS 3 assessment comprises $14.6-41.4 \%$ of all screening US $(11,15,16,18-21)$. However, the overall 
malignancy rate of BI-RADS 3 lesions is low, ranging from $0.2 \%$ to $1.7 \%(11,15,16,18,22,23)$. Cancers initially assessed as BI-RADS 3 and detected during follow-up are still in the early stage of malignancy while being small in size, ranging from $2 \mathrm{~mm}$ to $18 \mathrm{~mm}$ in size $(11,15,16,18$, $22,23)$. Most cases in past studies have had no axillary lymph node metastasis $(11,15,16,18,22)$. Therefore, previous reports suggested one-year follow-up for women with BI-RADS 3 lesions on screening US $(11,16,21,22)$, and criteria to downgrade the initial BI-RADS category 3 assessment to category 2 (24).

In tertiary referral centers, screening breast US is performed for asymptomatic women with negative or benign findings on their screening mammogram. Community hospitals and private clinics selectively refer women to tertiary centers for screening US. Asymptomatic women with gynecological malignancies, including ovarian cancer, or receiving hormonal replacement therapy undergo screening US at tertiary centers. The characteristics of women who undergo screening US at screening centers may be different from those of women screened at tertiary centers. To our knowledge, no study has compared follow-up intervals and follow-up results in women with BI-RADS 3 lesions on screening US between screening and tertiary centers.

Therefore, we aimed to assess the appropriate followup interval, and rate and timepoint of cancer detection in women with BI-RADS 3 lesions on screening US according to the type of institution.

\section{MATERIALS AND METHODS}

The Institutional Review Board approved this retrospective study and required neither patient approval nor informed consent for our review of patient images and medical records.

\section{Study Population}

In our institution, the screening center is a separate facility and at a separate site from the main institution which is a tertiary center. From March 2013 to February 2015, 4776 screening US examinations were performed in the screening center and 1118 women (23.4\%) without prior breast cancer surgery were initially assessed as BIRADS 3. Among them, 349 women without at least 6 months of follow-up and 70 women with probably benign lesions on screening mammogram and/or additional mammogram were excluded. A total of 699 women with negative or benign mammogram findings ( $n=664$ ) or without mammogram examinations $(n=35)$ were included in our study.

In the tertiary center, the purpose of the US examination was recorded on the radiologic report. Screening US was defined as US examinations performed for asymptomatic women with negative or benign assessment of screening mammograms at outside hospitals or who did not undergo mammography, asymptomatic women with negative or benign assessment on previous US and mammography at our institution, or asymptomatic women with gynecological disease or receiving hormonal replacement therapy with negative or benign screening mammograms. Breast US examinations performed on women who had undergone prior breast cancer surgery were not defined as screening US. Among 43950 US examinations performed in the tertiary center, 8846 US examinations were performed in the screening setting. Of 828 women with BI-RADS 3 assessment on screening US $(9.4 \%), 52$ women without at least 6 months of follow-up and 24 with probably benign lesions on mammograms were excluded. Finally, 752 women with negative or benign mammogram results $(n=663)$ or who did not undergo mammographic examination $(n=89)$ were included in our study.

\section{Mammographic and US Examinations}

In the screening center, screening US examinations and mammogram interpretations were performed by five boardcertified radiologists with 3 to 7 years of experiences in breast imaging. Two of the radiologists had completed one year of fellowship training for breast imaging while the other three had only completed their residency training. Mammograms were obtained using dedicated equipment for digital mammography (Lorad Selenia, Hologic, Danbury, CT, USA). Mammography was usually performed on the same day as the screening US. US examinations were performed using high-resolution US equipment (iU22, Phillips-Advanced Technology Laboratories, Bothell, WA, USA) with a 5-12-MHz linear array transducer.

In the tertiary center, screening US examination and mammogram interpretation were performed by 11 boardcertified radiologists dedicated to breast imaging with 1 to 20 years of experience in breast imaging. Mammograms were obtained using dedicated equipment for digital mammography (Senographe DS, GE Healthcare, Milwaukee, WI, USA; Lorad Selenia) and digital tomosynthesis (Selenia Dimensions, Hologic). In the screening setting, only 2-dimensional mammograms were obtained, with no 
tomosynthesis. High-resolution US equipment (iU22; LOGIQ 9, GE Healthcare) and 5-12- or 7-12-MHz linear array transducers were used. Mammograms and US examinations were originally reported according to the ACR BI-RADS in both centers (17).

In both the tertiary and screening centers, standard mediolateral oblique and craniocaudal views were obtained. Additional views were obtained when needed. For this study, an available mammogram was defined as a mammogram obtained 6 months before or after the screening US. Screening US included bilateral whole breasts and the axillae. Lesions were assessed as category 3 on US based on the following features: an oval circumscribed bordered mass parallel to the skin and no or minimal posterior enhancement, a hyperechoic mass with central hypo- or anechogenity suggesting fat necrosis, a hypoechoic mass with a homogeneous low-level internal echo, and a clustered microcyst $(13,16,17)$. Orthogonal images with and without calipers were documented for all lesions detected on US, and Doppler US was used for lesion characterization. After 6 months, follow-up breast US was performed. If cancer was diagnosed at this time, mammography or tomosynthesis was additionally performed. At 12 months, both follow-up US and mammography were performed. Follow-up breast US at 6 and 12 months included bilateral whole breasts and axillae.

In both centers, the radiologists or clinicians checked each patient's family history of breast cancer and history of hormone replacement therapy and wrote in the radiologic reports or electronic medical records. We reviewed both for all patients included in this study.

\section{Data and Statistical Analysis}

Age, prevalence or incidence screening US, family history of breast cancer, hormone replacement therapy, malignancy rate, and follow-up interval from the date of initial BIRADS 3 assessment to the date of last follow-up or cancer detection, and pathological characteristics of the detected cancers were compared between the two centers. For cancer cases, we classified detection intervals into two categories; "at 6 months," which included cancers detected 6-9 months after initial BI-RADS 3 assessment, and "after 12 months," which included cancers detected after 12 months. Women were subclassified and analyzed according to their mammographic breast density (fatty and dense mammography density) and whether they were 40 years or older. Of 1451 women, 124 did not have a mammogram available and were included in the dense mammographic density subgroup because 95 of the 124 women were younger than 40 years old. Nominal variables were compared using the chi-square or Fisher's exact test and continuous variables were compared using the independent $t$ test or Mann-Whitney $\mathrm{U}$ test. Statistical analyses were performed using SPSS (version 23.0, IBM Corp., Armonk, NY, USA) software. A two-sided $p<0.05$ was considered to indicate statistical significance.

\section{RESULTS}

Mean age and mammographic density were not significantly different between the two centers $(p=0.281$ and 0.223 , respectively) (Table 1 ). The mean followup interval from the initial assessment to last contact or cancer diagnosis was longer in the tertiary center than in the screening center $(p<0.001)$. Prevalence screening US $(76.7 \%, 536$ of 699$)$ was more frequently performed in the screening center than in the tertiary center $(44.4 \%, 334$ of 752) $(p<0.001)$. In the tertiary center, 72 women $(9.6 \%)$ had a family history of breast cancer; in the screening center, 29 women $(4.1 \%)$ had a family history of breast cancer $(p<0.001)$. In the tertiary center, $140(18.6 \%)$ of 752 women underwent hormone replacement therapy, while in the screening center, 37 (5.3\%) of 699 women underwent hormone replacement therapy $(p<0.001)$.

Of 1451 women, 19 cancers (1.3\%) in 19 women were diagnosed during follow-up. Seventeen cancers were invasive and two cancers were in situ. Three cancers (0.2\%) were BI-RADS 3 lesions progressing at 7.7, 12.4, and 21.2 months, and 16 cancers (1.1\%) newly developed. Only two cancers $(0.1 \%)$ were diagnosed at 6 months and $17(1.2 \%)$ were diagnosed after 12 months. Nine cancers $(1.3 \%$ of $699)$ were diagnosed at the screening center and $10(1.3 \%$ of 752) at the tertiary center. The malignancy rates did not differ between the two centers $(p>0.999)$. Six cancers from the screening center were detected on prevalence US and eight cancers from the tertiary center were detected on incidence US, which was not significantly different between centers $(p=0.070)$.

When a cut-off age of 40 years was applied, the mean follow-up interval to last contact or cancer diagnosis was longer in the tertiary center $(33.3 \pm 11.4$ months, $p=0.001)$ for 1138 women 40 years or older (Table 2). Of 1356 women with dense mammography density, the mean follow-up interval to last contact or cancer diagnosis was longer in the 
tertiary center $(33.5 \pm 11.3$ months, $p<0.001)$ (Table 3).

The characteristics of the 19 cancers, including one case with axillary lymph node metastasis (5.3\%, 1 of 19), are listed in Table 4. Median age, cancer diagnosis according to the cut-off age of 40 years, mean interval to cancer diagnosis, and diagnosis at 6 months or after 12 months

Table 1. Comparisons of Clinic-Pathological Characteristics between Screening and Tertiary Center

\begin{tabular}{|c|c|c|c|}
\hline Characteristics & Screening Center $(n=699)$ & Tertiary Referral Center $(n=752)$ & $P$ \\
\hline Mean age (years, SD) & $47.4 \pm 9.3$ & $47.9 \pm 9.7$ & 0.281 \\
\hline Mean follow-up interval* (months, SD) & $30.9 \pm 11.2$ & $33.2 \pm 11.5$ & $<0.001$ \\
\hline Mammographic density (\%) & & & 0.223 \\
\hline Grade $A$ and $B(n=95)$ & $52(7.4)$ & $43(5.7)$ & \\
\hline Grade $C$ and $D(n=1356)$ & $647(92.6)$ & $709(94.3)$ & \\
\hline US screening $(\%)$ & & & $<0.001$ \\
\hline Prevalence $(n=870)$ & $536(76.7)$ & $334(44.4)$ & \\
\hline Incidence $(n=581)$ & $163(23.3)$ & $418(55.6)$ & \\
\hline Family history (\%) & & & $<0.001$ \\
\hline Yes & $29(4.1)$ & $72(9.6)$ & \\
\hline No & $670(95.9)$ & $680(90.4)$ & \\
\hline Hormone replacement therapy (\%) & & & $<0.001$ \\
\hline Yes & $37(5.3)$ & $140(18.6)$ & \\
\hline No & $662(94.7)$ & $612(84.1)$ & \\
\hline Cancer detection rate during follow-up $(n=19)(\%)$ & $9(1.3)$ & $10(1.3)$ & $>0.999$ \\
\hline Cancer detection interval (\%) & & & 0.500 \\
\hline At 6 months $(n=2)$ & $0(0)$ & $2(0.3)$ & \\
\hline After 12 months $(n=17)$ & $9(1.3)$ & $8(1.1)$ & \\
\hline Cancer detection rate according to US screening (\%) & & & 0.070 \\
\hline Prevalence & $6(0.9)$ & $2(0.3)$ & \\
\hline Incidence & $3(0.4)$ & $8(1.1)$ & \\
\hline
\end{tabular}

*Follow-up to last contact or cancer diagnosis. SD = standard deviation, US = ultrasonography

Table 2. Comparisons of Clinic-Pathological Characteristics according to Cut-0ff Age of 40 Years

\begin{tabular}{|c|c|c|c|c|c|c|c|}
\hline \multirow[b]{2}{*}{ Characteristics } & \multicolumn{3}{|c|}{ Less than 40 Years $(n=313)$} & \multirow[b]{2}{*}{ Characteristics } & \multicolumn{3}{|c|}{40 Years or Older $(n=1138)$} \\
\hline & $\begin{array}{l}\text { Screening } \\
\text { Center } \\
(n=161)\end{array}$ & $\begin{array}{c}\text { Tertiary } \\
\text { Referral } \\
\text { Center } \\
(n=152)\end{array}$ & $P$ & & $\begin{array}{l}\text { Screening } \\
\text { Center } \\
(n=538)\end{array}$ & $\begin{array}{c}\text { Tertiary } \\
\text { Referral } \\
\text { Center } \\
(n=600)\end{array}$ & $P$ \\
\hline Mean age (years, SD) & $34.8 \pm 3.7$ & $34.0 \pm 4.3$ & 0.093 & Mean age (years, SD) & $51.2 \pm 6.9$ & $51.4 \pm 7.2$ & 0.486 \\
\hline $\begin{array}{l}\text { Mean follow-up interval* } \\
\text { (months, SD) }\end{array}$ & $30.5 \pm 10.5$ & $32.8 \pm 11.7$ & 0.074 & $\begin{array}{l}\text { Mean follow-up interval* } \\
\text { (months, SD) }\end{array}$ & $31.0 \pm 11.4$ & $33.3 \pm 11.4$ & 0.001 \\
\hline Mammographic density (\%) & & & $>0.999$ & Grade on mammogram (\%) & & & 0.190 \\
\hline Grade $A$ and $B(n=5)$ & $3(1.9)$ & $2(1.3)$ & & Grade $A$ and $B(n=90)$ & $49(9.1)$ & $41(6.8)$ & \\
\hline Grade $C$ and $D(n=308)$ & $158(98.1)$ & $150(98.7)$ & & Grade $C$ and $D(n=1048)$ & $489(90.9)$ & $559(93.2)$ & \\
\hline $\begin{array}{l}\text { Cancer detection rate } \\
\text { during follow-up }(n=2)(\%)\end{array}$ & $2(1.2)$ & $0(0)$ & 0.499 & Malignancy rate $(n=17)(\%)$ & $7(1.3)$ & $10(1.7)$ & 0.793 \\
\hline
\end{tabular}

*Follow-up to last contact or cancer diagnosis.

Table 3. Comparisons of Clinic-Pathological Characteristics according to Breast Density

\begin{tabular}{|c|c|c|c|c|c|c|}
\hline \multirow[b]{2}{*}{ Characteristics } & \multicolumn{3}{|c|}{ Fatty Breast $(n=95)$} & \multicolumn{3}{|c|}{ Dense Breast $(n=1356)$} \\
\hline & $\begin{array}{c}\text { Screening } \\
\text { Center }(n=52)\end{array}$ & $\begin{array}{l}\text { Tertiary Referral } \\
\text { Center }(n=43)\end{array}$ & $P$ & $\begin{array}{c}\text { Screening } \\
\text { Center }(n=647)\end{array}$ & $\begin{array}{l}\text { Tertiary Referral } \\
\text { Center }(n=709)\end{array}$ & $P$ \\
\hline Mean age (years, SD) & $54.3 \pm 9.2$ & $54.9 \pm 7.4$ & 0.731 & $46.8 \pm 9.1$ & $47.5 \pm 9.6$ & 0.189 \\
\hline Mean follow-up interval* (months, SD) & $34.0 \pm 11.9$ & $32.4 \pm 13.0$ & 0.551 & $30.8 \pm 11.1$ & $33.5 \pm 11.3$ & $<0.001$ \\
\hline Cancer detection rate during follow-up (\%) & $1(2.3)$ & $0(0)$ & 0.453 & $9(1.4)$ & $98(1.3)$ & $>0.999$ \\
\hline
\end{tabular}

*Follow-up to last contact or cancer diagnosis. 
were not significantly different between the two centers (all $p>0.05$ ) (Table 5). All nine cancers found in the screening center were invasive, a median $9 \mathrm{~mm}$ (range, 2-12 mm) in size, without lymph node metastasis and diagnosed after 12.3 months. No cancers were found at 6 months in the screening center. Even though two cancers in the screening center showed progression at 12.4 months and 21.2 months, they were invasive cancers $9 \mathrm{~mm}$ and $12 \mathrm{~mm}$ in size without lymph node metastasis. In the tertiary center, eight were invasive cancers and two were ductal carcinomas

Table 4. Clinicopathologic Features of 19 Detected Cancers from Breast Imaging Reporting and Data System Category 3

\begin{tabular}{|c|c|c|c|c|c|c|c|c|}
\hline No. & $\begin{array}{c}\text { Age } \\
\text { (years) }\end{array}$ & $\begin{array}{l}\text { Interval to } \\
\text { Cancer } \\
\text { (Months) }\end{array}$ & $\begin{array}{c}\text { Symptoms at } \\
\text { Cancer Diagnosis }\end{array}$ & $\begin{array}{l}\text { Detection } \\
\text { Center }\end{array}$ & Pathology & $\begin{array}{c}\text { Size on } \\
\text { Pathology } \\
(\mathrm{mm})\end{array}$ & $\begin{array}{l}\text { Node } \\
\text { Status }\end{array}$ & Features of Cancer Detection \\
\hline 1 & 57 & 12.3 & None & $S$ & IDC & 9 & 0 & $\begin{array}{l}\text { New } \\
\text { Non-visible on MG }\end{array}$ \\
\hline 2 & 59 & 12.4 & Palpable & $\mathrm{S}$ & $\begin{array}{r}\text { Metaplastic } \\
\text { carcinoma }\end{array}$ & 9 & 0 & $\begin{array}{l}\text { Increased size ( } 4 \mathrm{~mm} \text { to } 14 \mathrm{~mm} \text { ) } \\
\text { Mass on MG }\end{array}$ \\
\hline 3 & 49 & 21.2 & Palpable & $S$ & IDC & $12 *$ & Unknown & $\begin{array}{l}\text { Increased size }(10 \mathrm{~mm} \text { to } 12 \mathrm{~mm}) \\
\text { Mass on MG }\end{array}$ \\
\hline 4 & 46 & 26.1 & None & $S$ & IDC & 12 & 0 & $\begin{array}{l}\text { New } \\
\text { Non-visible on MG }\end{array}$ \\
\hline 5 & 37 & 28.5 & $\begin{array}{l}\text { Bloody nipple } \\
\text { discharge }\end{array}$ & $S$ & IDC & 2 & 0 & $\begin{array}{l}\text { New } \\
\text { Non-visible on tomosynthesis }\end{array}$ \\
\hline 6 & 37 & 31.8 & None & $S$ & IDC & $8^{*}$ & Unknown & $\begin{array}{l}\text { New } \\
\text { Non-visible on MG }\end{array}$ \\
\hline 7 & 49 & 33.1 & Palpable & $S$ & IDC & 7 & 0 & $\begin{array}{l}\text { New } \\
\text { Mass on MG }\end{array}$ \\
\hline 8 & 60 & 35.9 & Palpable & $S$ & IDC & 11 & 0 & $\begin{array}{l}\text { New } \\
\text { Mass on MG }\end{array}$ \\
\hline 9 & 40 & 36.9 & Palpable & $S$ & IDC & 7 & 0 & $\begin{array}{l}\text { New } \\
\text { Non-visible on MG }\end{array}$ \\
\hline 10 & 44 & 6.8 & None & $\mathrm{T}$ & IDC & 16 & 1 & $\begin{array}{l}\text { New } \\
\text { Mass on MG }\end{array}$ \\
\hline 11 & 68 & 7.7 & None & $\mathrm{T}$ & IDC & 7 & 0 & $\begin{array}{l}\text { Increased size ( } 5 \mathrm{~mm} \text { to } 7 \mathrm{~mm} \text { ) } \\
\text { Non-visible on } \mathrm{MG}\end{array}$ \\
\hline 12 & 55 & 13.1 & None & $\mathrm{T}$ & ILC & 10 & 0 & $\begin{array}{l}\text { New } \\
\text { Non-visible on MG }\end{array}$ \\
\hline 13 & 47 & 16.5 & None & $\mathrm{T}$ & DCIS & 24 & 0 & $\begin{array}{l}\text { New } \\
\text { Non-visible on MG }\end{array}$ \\
\hline 14 & 61 & 18.2 & None & $\mathrm{T}$ & IDC & 22 & 0 & $\begin{array}{l}\text { New } \\
\text { Microcalcifications on MG }\end{array}$ \\
\hline 15 & 53 & 20.6 & None & $\mathrm{T}$ & DCIS & 10 & 0 & $\begin{array}{l}\text { New } \\
\text { Mass on MG }\end{array}$ \\
\hline 16 & 43 & 25.3 & None & $\mathrm{T}$ & IDC & 4 & 0 & $\begin{array}{l}\text { New } \\
\text { Microcalcifications on MG }\end{array}$ \\
\hline 17 & 47 & 35.1 & None & $T$ & IDC & $7^{*}$ & Unknown & $\begin{array}{l}\text { New } \\
\text { Non-visible on MG }\end{array}$ \\
\hline 18 & 49 & 37.8 & None & $\mathrm{T}$ & IDC & 6 & 0 & $\begin{array}{l}\text { New } \\
\text { Mass on MG }\end{array}$ \\
\hline 19 & 56 & 38.3 & None & $\mathrm{T}$ & IDC & 13 & 0 & $\begin{array}{l}\text { New } \\
\text { Mass on MG }\end{array}$ \\
\hline
\end{tabular}

* Surgery was not performed at outside institution and size on US at time of cancer diagnosis was described. DCIS = ductal carcinoma in situ, IDC = invasive ductal carcinoma, ILC = invasive lobular carcinoma, MG = mammography, New = newly developed suspicious lesion on US, $\mathrm{S}=$ screening center, $\mathrm{T}=$ tertiary referral center 
Table 5. Characteristics of Detected Cancers

\begin{tabular}{|c|c|c|c|}
\hline Characteristics & Screening Center $(\mathrm{n}=9)$ & Tertiary Referral Center $(n=10)$ & $P$ \\
\hline Median age (years, range) & $49(37-60)$ & $51(43-68)$ & 0.400 \\
\hline Women 40 years or older $(n=17)(\%)$ & $7(77.8)$ & $10(100)$ & 0.211 \\
\hline Women less than 40 years $(n=2)(\%)$ & $2(22.2)$ & $0(0)$ & \\
\hline Median interval of cancer detection (months, range) & $28.5(12.3-36.9)$ & $19.4(6.8-38.3)$ & 0.179 \\
\hline Cancer detection interval & & & 0.474 \\
\hline At 6 months $(n=2)(\%)$ & $0(0)$ & $2(20.0)$ & \\
\hline After 12 months $(n=18)(\%)$ & $9(100)$ & $8(80.0)$ & \\
\hline Mammographic density (\%) & & & $>0.999$ \\
\hline Grade $A$ and $B(n=1)$ & $0(0)$ & $1(10.0)$ & \\
\hline Grade $C$ and $D(n=18)$ & $9(100)$ & $9(90.0)$ & \\
\hline Interval change of detected cancers (\%) & & & 0.582 \\
\hline Newly developed lesions $(n=16)$ & $7(77.8)$ & $9(90.0)$ & \\
\hline Increased size of existing lesions $(n=3)$ & $2(22.2)$ & $1(10.0)$ & \\
\hline Cancer type (\%) & & & 0.474 \\
\hline In situ cancer $(\mathrm{DCIS})(\mathrm{n}=2)$ & $0(0)$ & $2(20.0)$ & \\
\hline Invasive caner $(n=17)$ & $9(100)$ & $8(80.0)$ & \\
\hline Symptom at cancer diagnosis (\%) & & & 0.003 \\
\hline Bloody nipple discharge $(n=1)$ & $1(11.1)$ & $0(0)$ & \\
\hline Palpable lump $(\mathrm{n}=5)$ & $5(55.6)$ & $0(0)$ & \\
\hline Negative $(n=13)$ & $3(33.3)$ & $10(100)$ & \\
\hline Pathology $(n=16)^{*}$ & $(n=7)$ & $(n=9)$ & \\
\hline Median invasive tumor size (mm) & $9(2-12)$ & $10(4-22)$ & 0.535 \\
\hline T stage (\%) & & & 0.475 \\
\hline $0(n=2)$ & $0(0)$ & $2(22.2)$ & \\
\hline$T 1(n=13)$ & $7(100)$ & $6(66.7)$ & \\
\hline T2 $(n=1)$ & $0(0)$ & $1(11.1)$ & \\
\hline $\mathrm{N}$ stage $(\%)$ & & & $>0.999$ \\
\hline $0(n=7)$ & $7(100)$ & $8(88.9)$ & \\
\hline $1(n=1)$ & $0(0)$ & $1(11.1)$ & \\
\hline
\end{tabular}

* Of 19 women with cancers, 16 underwent surgery in our institution.

in situ. Two cancers $(0.3 \%, 2$ of 752$)$ in the tertiary center were diagnosed at 6.8 months and 7.7 months; one showing progression at 7.7 months was a $7-\mathrm{mm}$ invasive cancer without lymph node metastasis (Fig. 1) and the other newly developing at 6.8 months was a $16-\mathrm{mm}$ invasive cancer with one axillary lymph node metastasis (Fig. 2). The other eight cancers were newly developing cancers diagnosed after 13.1 months; six invasive cancers were $4 \mathrm{~mm}$ to $22 \mathrm{~mm}$ in size without lymph node metastasis and two were in situ cancers. At the time of cancer diagnosis, symptoms such as palpable lumps $(n=5)$ and bloody nipple discharge $(n=1)$ were more frequently present in the screening center $(66.7 \%$ of 9 cancers) than in the tertiary center ( $0 \%$ of 10 cancers) $(p=0.003)$. Of the 19 women with cancer, 16 underwent surgery at our institution. Tumor size on pathology, T stage, and $\mathrm{N}$ stage were not significantly different between the two centers (all $p>0.05$ ).

\section{DISCUSSION}

In our study, the malignancy rates in women with the BI-RADS 3 assessment on screening US were both 1.3\% in the screening and tertiary centers, which was less than the $2 \%$ of the recommended range (17) and comparable with previous studies $(10,11,15-18,22)$. Two cancers $(0.1 \%)$ were diagnosed at 6 months; one progressed from a BI-RADS 3 lesion and the other was a new cancer. The remaining $17(1.2 \%)$ were diagnosed after 12.3 months. At 6 months, the malignancy rates were $0 \%$ in the screening center and $0.3 \%$ in the tertiary center. Three cancers $(0.2 \%)$ progressed from BI-RADS 3 lesions at 7.7, 12.4, and 21.2 months while the other $16(1.1 \%)$ were newly developed cancers.

For BI-RADS 3 lesions on screening mammograms, such as non-calcified solid masses with round or oval 
shape, a solitary group of round microcalcifications, or focal asymmetry without associated calcifications (2529), a 6-month follow-up is recommended due to the low malignancy rate, detection of mostly early-stage cancers after 6 months, and cost reduction with immediate biopsy
$(17,25,27,30)$. Similar strategies are applied to BI-RADS 3 lesions identified on screening US (17). However, the effectiveness of a 6-months follow-up US is questionable $(15,16,21,22)$. Furthermore, the very low malignancy rates of $0.2 \%$ to $1.0 \%(11,15,16,18,21-23)$ and high

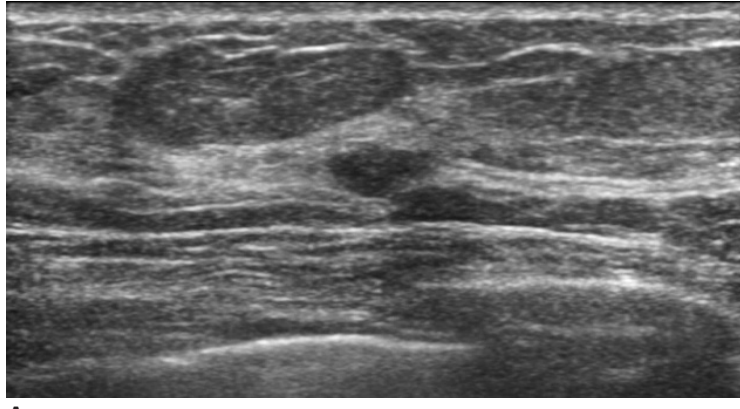

A

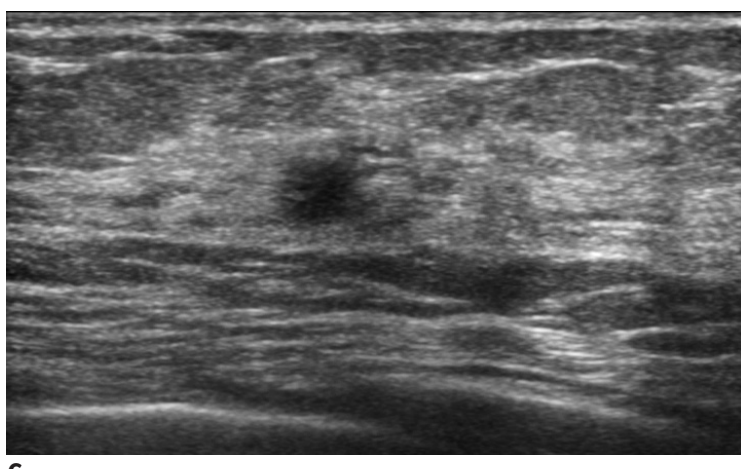

C

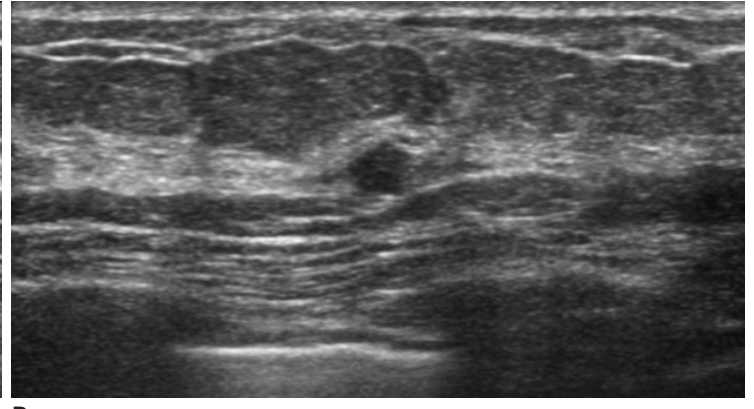

B

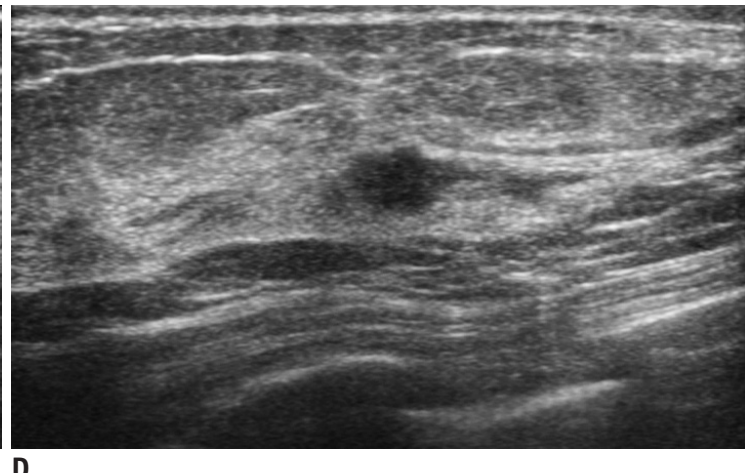

Fig. 1. 68-year-old women with benign calcifications on screening mammogram and BI-RADS category 3 lesion on screening US performed at tertiary center.

A. Initial transverse. B. Initial longitudinal scan. Initially, 5-mm-sized lesion was assessed as BI-RADS category 3. C. Follow-up transverse. D. Follow-up longitudinal scan. At 7.7 months of follow-up, lesion progressed to $7 \mathrm{~mm}$ in size with suspicious features. This change was not detected on mammogram at 7.7 months. It was 7-mm-sized triple-negative invasive ductal carcinoma with nuclear grade 2 and without axillary lymph node metastasis on surgical pathology. BI-RADS = Breast Imaging Reporting and Data System, US = ultrasonography

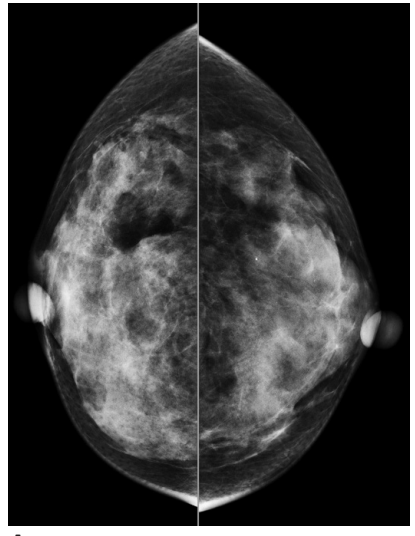

A
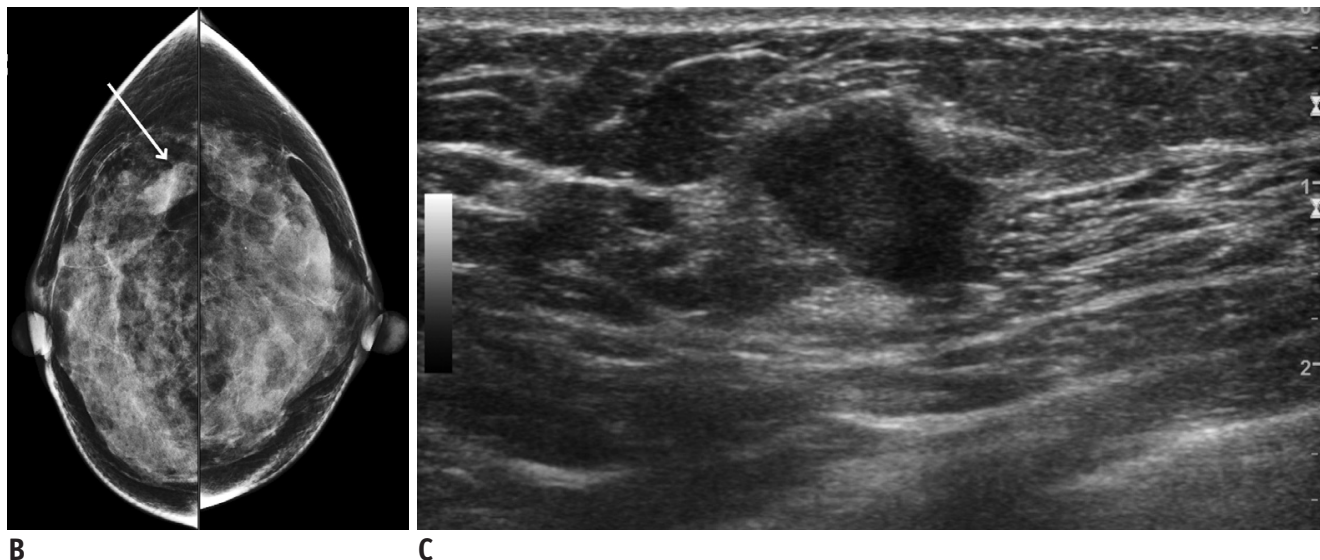

C

Fig. 2. 48-year-old woman had benign findings on screening mammogram and BI-RADS category 3 lesions on screening US performed at tertiary center.

A. Screening mammogram. B. Follow-up mammogram. C. Follow-up US. All BI-RADS 3 lesions showed no change on follow-up US at 6.8 months. However, new 14-mm-sized BI-RADS category 4C lesion was detected on both US and mammogram (arrow). It was 16-mm-sized luminal A type invasive ductal carcinoma with nuclear grade 2 and metastasis to one axillary lymph node on surgical pathology. 
false-positive rates of US examinations during follow-up are problematic. A previous study found newly developed BIRADS 3 lesions in $26.4 \%, 23.6 \%$, and $24.6 \%$ of all cases in year 1,2, and 3, respectively, despite the low malignancy rate (16). Prior reports recommended one year of followup for multiple bilateral circumscribed masses or BI-RADS 3 lesions on screening US $(22,31)$. Of 1451 women, only three cancers $(0.2 \%)$ progressed from BI-RADS 3 lesions at 7.7, 12.4, and 21.2 months. In our screening center, the malignancy rate was $1.3 \%$ and all malignancies were diagnosed after 12.3 months. Therefore, a one-year followup might be recommended in the screening center. In the tertiary centers, two malignancies $(0.3 \%)$ were diagnosed at the 6-month follow-up; therefore, more caution is needed in tertiary centers and a 6-month follow-up may remain appropriate.

Most cancers in previous studies diagnosed after initial BI-RADS 3 assessment on screening US were T1 stage (range, 2-18 mm) $(11,15,16,18,22,23)$ without lymph node metastasis $(11,15,18,22)$. In our screening center, all nine invasive cancers were detected after 12.3 months with a median tumor size of $9 \mathrm{~mm}$ (range, 2-12 mm) and without lymph node metastasis. Two malignancies with progression after the initial BI-RADS 3 assessment at 12.4 months and 21.2 months were $9-\mathrm{mm}$ and $12-\mathrm{mm}$ invasive cancers without lymph node metastasis. Therefore, in the screening center, a one-year follow-up might be cautiously recommended for BI-RADS 3 lesions. In the tertiary center, two invasive cancers were diagnosed at 6 months; one progressing from a BI-RADS 3 lesion was a 7-mm invasive cancer without axillary lymph node metastasis and the other was a new $16-\mathrm{mm}$ invasive cancer with one axillary lymph node metastasis. In the tertiary center, more caution is needed and a 6-month-follow-up in the tertiary center may be appropriate.

Our study has some limitations. First, it was a retrospective study and 495 of 1946 women were excluded. A selection bias might exist, and malignancy rates might be overestimated. However, the overestimation would not change our results. Second, data from screening breast US performed at a single tertiary center and its branch screening center were included. A multicenter study is needed to generalize our findings. Third, US examinations were performed by 16 radiologists and inter-observer variability might exist. Inter-observer variability was not analyzed in this study. However, the inclusion of many radiologists with differing levels of experience is reflective of routine daily practice.

In conclusion, one-year follow-up rather than 6-month follow-up might be more appropriate for BI-RADS 3 lesions identified during screening US in screening centers. However, more caution is needed in tertiary centers where a 6-month follow-up may be more appropriate.

\section{Conflicts of Interest}

The authors have no potential conflicts of interest to disclose.

\section{ORCID iDs}

Hee Jung Moon

https://orcid.org/0000-0002-5643-5885

Sun Huh

https://orcid.org/0000-0002-4413-6255

Eun-Kyung Kim

https://orcid.org/0000-0002-3368-5013

Min Jung Kim

https://orcid.org/0000-0003-4949-1237

Jung Hyun Yoon

https://orcid.org/0000-0002-2100-3513

Vivian Youngjean Park

https://orcid.org/0000-0002-5135-4058

\section{REFERENCES}

1. Michaelson JS, Silverstein M, Sgroi D, Cheongsiatmoy JA, Taghian A, Powell S, et al. The effect of tumor size and lymph node status on breast carcinoma lethality. Cancer 2003; 98:2133-2143

2. Kolb TM, Lichy J, Newhouse JH. Comparison of the performance of screening mammography, physical examination, and breast US and evaluation of factors that influence them: an analysis of 27,825 patient evaluations. Radiology 2002;225:165-175

3. Mandelson MT, Oestreicher N, Porter PL, White D, Finder CA, Taplin SH, et al. Breast density as a predictor of mammographic detection: comparison of interval- and screendetected cancers. J Natl Cancer Inst 2000;92:1081-1087

4. Chae EY, Kim HH, Cha JH, Shin HJ, Kim H. Evaluation of screening whole-breast sonography as a supplemental tool in conjunction with mammography in women with dense breasts. J Ultrasound Med 2013;32:1573-1578

5. Gordon PB, Goldenberg SL. Malignant breast masses detected only by ultrasound. A retrospective review. Cancer 1995;76:626-630

6. Chang JM, Koo HR, Moon WK. Radiologist-performed handheld ultrasound screening at average risk of breast cancer: results from a single health screening center. Acta Radiol 
2015;56:652-658

7. Corsetti V, Ferrari A, Ghirardi M, Bergonzini R, Bellarosa $S$, Angelini 0 , et al. Role of ultrasonography in detecting mammographically occult breast carcinoma in women with dense breasts. Radiol Med 2006;111:440-448

8. De Felice C, Savelli S, Angeletti M, Ballesio L, Manganaro $\mathrm{L}$, Meggiorini ML, et al. Diagnostic utility of combined ultrasonography and mammography in the evaluation of women with mammographically dense breasts. J Ultrasound 2007;10:143-151

9. Girardi V, Tonegutti M, Ciatto S, Bonetti F. Breast ultrasound in 22,131 asymptomatic women with negative mammography. Breast 2013;22:806-809

10. Moon HJ, Jung I, Park SJ, Kim MJ, Youk JH, Kim EK. Comparison of cancer yields and diagnostic performance of screening mammography vs. supplemental screening ultrasound in 4394 women with average risk for breast cancer. Ultraschall Med 2015;36:255-263

11. Nam SY, Ko EY, Han BK, Shin JH, Ko ES, Hahn SY. Breast imaging reporting and data system category 3 lesions detected on whole-breast screening ultrasound. J Breast Cancer 2016;19:301-307

12. Hwang JY, Han BK, Ko EY, Shin JH, Hahn SY, Nam MY. Screening ultrasound in women with negative mammography: outcome analysis. Yonsei Med J 2015;56:1352-1358

13. Berg WA, Blume JD, Cormack JB, Mendelson EB, Lehrer D, Böhm-Vélez $M$, et al. Combined screening with ultrasound and mammography vs mammography alone in women at elevated risk of breast cancer. JAMA 2008;299:2151-2163

14. Hooley RJ, Greenberg KL, Stackhouse RM, Geisel JL, Butler RS, Philpotts LE. Screening US in patients with mammographically dense breasts: initial experience with Connecticut Public Act 09-41. Radiology 2012;265:59-69

15. Chae EY, Cha JH, Shin HJ, Choi WJ, Kim HH. Reassessment and follow-up results of BI-RADS category 3 lesions detected on screening breast ultrasound. AJR Am J Roentgenol 2016;206:666-672

16. Barr RG, Zhang Z, Cormack JB, Mendelson EB, Berg WA. Probably benign lesions at screening breast US in a population with elevated risk: prevalence and rate of malignancy in the ACRIN 6666 trial. Radiology 2013;269:701712

17. American College of Radiology. Breast imaging reporting and data system, 5th ed. Reston: American College of Radiology, 2013

18. Kim SJ, Chang JM, Cho N, Chung SY, Han W, Moon
WK. Outcome of breast lesions detected at screening ultrasonography. Eur J Radiol 2012;81:3229-3233

19. Moon HJ, Kim EK, Kwak JY, Yoon JH, Kim MJ. Interval growth of probably benign breast lesions on follow-up ultrasound: how can these be managed? Eur Radiol 2011;21:908-918

20. Kaplan SS. Clinical utility of bilateral whole-breast US in the evaluation of women with dense breast tissue. Radiology 2001;221:641-649

21. Ruamsup S, Wiratkapun C, Wibulpolprasert B, Lertsithichai P. A comparison between short-interval and regular-interval follow-up for BI-RADS category 3 lesions. Singapore Med J 2010;51:120-125

22. Moon HJ, Kim MJ, Yoon JH, Kim EK. Follow-up interval for probably benign breast lesions on screening ultrasound in women at average risk for breast cancer with dense breasts. Acta Radiol 2018;59:1045-1050

23. Gruber R, Jaromi S, Rudas M, Pfarl G, Riedl CC, Flöry D, et al. Histologic work-up of non-palpable breast lesions classified as probably benign at initial mammography and/or ultrasound (BI-RADS category 3). Eur J Radiol 2013;82:398-403

24. Kim SY, Kim MJ, Moon HJ, Yoon JH, Kim EK. Application of the downgrade criteria to supplemental screening ultrasound for women with negative mammography but dense breasts. Medicine (Baltimore) 2016;95:e5279

25. Michaels AY, Birdwell RL, Chung CS, Frost EP, Giess CS. Assessment and management of challenging BI-RADS category 3 mammographic lesions. Radiographics 2016;36:1261-1272

26. Helvie MA, Pennes DR, Rebner M, Adler DD. Mammographic follow-up of low-suspicion lesions: compliance rate and diagnostic yield. Radiology 1991;178:155-158

27. Sickles EA. Periodic mammographic follow-up of probably benign lesions: results in 3,184 consecutive cases. Radiology 1991;179:463-468

28. Vizcaíno I, Gadea L, Andreo L, Salas D, Ruiz-Perales F, Cuevas $D$, et al. Short-term follow-up results in 795 nonpalpable probably benign lesions detected at screening mammography. Radiology 2001;219:475-483

29. Varas X, Leborgne F, Leborgne JH. Nonpalpable, probably benign lesions: role of follow-up mammography. Radiology 1992;184:409-414

30. Cyrlak D. Induced costs of low-cost screening mammography. Radiology 1988;168:661-663

31. Berg WA, Zhang Z, Cormack JB, Mendelson EB. Multiple bilateral circumscribed masses at screening breast US: consider annual follow-up. Radiology 2013;268:673-683 